perpetrator (if there are grounds for this) must be qualified according to the totality of crimes provided for by part 1 and part 3 (or part 2 and h. 4) Art. 197-1 of the Criminal Code of Ukraine.

It is substantiated that the actions of a person who, having taken possession of a land plot, transfers it for use to other persons who, being confident in the legality of the actions performed, carry out construction on it, should receive a criminal law assessment with reference only to part 1 (part 2 ) Art. 197-1 of the Criminal Code of Ukraine, since further construction activities were not covered by its intent; and also the fact that the actions of persons who began construction work on an unauthorized occupied land should be qualified as a completed corpus delicti, provided for in part 3 (part 4) of Art. 197-1 of the Criminal Code of Ukraine.

Key words: unauthorized occupation, unauthorized construction, land, criminal liability, qualifications, set of crimes.

DOI: 10.33766/2524-0323.88.134-147

УДК 351.752.2

М. А. Самбор, кандидат юридичних наук, начальник сектора моніторингу Прилуцького відділу поліції Головного управління Національної поліції в Чернігівській області

(м. Чернігів - м. Прилуки, Україна) e-mail: NIKOLAS783@ukr.net iDhttps://orcid.org/ 0000-0002-0446-3892

\title{
ПОВНОВАЖЕННЯ ОРГАНІВ НАЦОНАЛЬНОЇ ПОЛІЦІЇ УКРАЇНИ ПІД ЧАС ЗАБЕЗПЕЧЕННЯ ЗДІЙСНЕННЯ ПРАВА НА СВОБОДУ МИРНИХ ЗІБРАНЬ
}

У праві в постійному взаємозв'язку перебувають такі парні категорії, як права й обов'язки. Право на свободу мирних зібрань не є винятком, а тому кореспондується із обов'язками суб'єктів публічної адміністрації, завданням яких є забезпечення безперешкодного здійснення права на свободу мирних зібрань. Тож у публікації детально розглянуто повноваження органів Національної поліції України, спрямовані на забезпечення здійснення права на свободу мирних зібрань. Обгрунтовано необхідність розмежування повноважень органів Національної поліції на трьох основних етапах щодо забезпечення правопорядку під час мирних заходів: 1) під час підготовки до проведення мирного зібрання; 2) під час мирного зібрання. 3) після завершення мирного зібрання; а також на чотирьох етапах забезпечення безперешкодного здійснення права на свободу мирних зібрань органами Національної поліції України: 1) попередній; 2) підготовчий; 3) практичний; 4) завершальний (підсумковий).

Ключові слова: право на свободу мирних зібрань, повноваження, Національна поліція України.

Постановка проблеми. Держава, як особливий інститут об'єднання населення, в особі уповноважених органів та посадових осіб, а саме правоохоронних органів, 
покликана створити умови для нормального співжиття всіх ї̈ громадян та осіб, які погодилися проживати в межах відповідного політико-територіального об'єднання, що й вирізняє ії з-поміж інших суспільних інститутів. Одним із ключових аспектів та призначень держави є забезпечення повноцінного розвитку особистості, забезпечення умов безперешкодного здійснення кожним членом соціуму його прав і свобод, інтересів. Кожне із прав, свобод та інтересів вирізняється серед інших особливостями ïx здійснення, водночас держава має гарантувати можливість кожному здійснювати права, свободи та інтереси відповідно до його прагнень та спрямованості з урахуванням певного балансу й стабільності суспільних відносин та інтересів кожного члена суспільства.

Без перебільшення, одним із ключових прав і свобод є право на свободу мирних зібрань. Зазвичай право на свободу мирних зібрань ототожнюється із самим зібранням. Однак такий підхід є викривленим, оскільки суб'єктивну можливість, гарантовану людині, зводити виключно до певного заходу, пов'язаного із присутністю в одному місці значної кількості людей, об' єднаних спільним інтересом, не правильно, тому що такий підхід нівелює складний процес здійснення права, зводячи його виключно до певного результату, який, до речі, не обов'язково, як свідчить законодавча практика, пов'язується із присутністю великої кількості людей в одному місці.

Аналіз останніх досліджень і публікацій. У контексті всебічного вивчення права на свободу мирних зібрань маємо зауважити, що питання захисту та охорони цього права з боку правоохоронних органів, зокрема Національної поліції, є лише частково дослідженими, оскільки мають місце наукові розвідки саме забезпечення правопорядку під час масових заходів, а не надавання здійснення права на свободу мирних зібрань, не ведучи мову про охорону та захист цього права. Дослідники забезпечення громадського (публічного) порядку зводили свої пошуки виключно до забезпечення правопорядку під час масових заходів, тоді як питання надавання здійснення права на свободу мирних зібрань залишалося відкритим. Переконливим підтвердженням цього $є$ здійснені дисертаційні дослідження з цього питання. Для прикладу, А. В. Долинний вивчав адміністративно-правове забезпечення Національною поліцією України публічної безпеки під час масових заходів [1], В. Г. Поліщук зосередив увагу на адміністративно-правовому регулюванні та практиці проведення масових заходів [2], М. В. Возник обрав за предмет дослідження організаційно-правові засади управління органами внутрішніх справ при забезпеченні масових заходів [3], В. Ф. Нестерович розглядав право на свободу мирних зібрань у конституційно-правовій площині $[4,5]$ тощо. Дослідники, як правило, конщентрують увагу, саме на об'єкті забезпечення правопорядку - мирному зібранні, тоді як заходи щодо надання здійснення права на свободу мирних зібрань $є$ значно ширшими та потребують білышого наукового пошуку, не загострюючи увагу виключно на самих мирних зібраннях. Як наслідок, питання правового регулювання щодо забезпечення здійснення саме права на свободу мирних зібрань не досліджувалося.

Формування цілей. Ураховуючи викладене, метою статті є дослідження повноважень органів Національної поліції України під час забезпечення здійснення права на свободу мирних зібрань.

Виклад основного матеріалу. На початку більш детально розглянемо повноваження органів Національної поліції України. Згідно зі ст. 2 Закону України «Про Національну поліцію», завданнями поліції є надання поліцейських послуг у таких сферах: 1) забезпечення публічної безпеки й порядку; 2) охорони прав і свобод людини, а також інтересів суспільства і держави; 3) протидії злочинності; 4) надання 
в межах, визначених законом, послуг 3 допомоги особам, які 3 особистих, економічних, соціальних причин або внаслідок надзвичайних ситуацій потребують такої допомоги. Навряд чи можна сказати, що законодавець вказані повноваження розмістив в алфавітно-хронологічному порядку, скоріше за все ці завдання розташовані саме у функціональному порядку, виходячи із побажань суб'єкта їх реалізації або необхідності їх виконання тим-таки суб'єктом, ніж із використанням аксіологічного підходу. Тому виходить так, що пріоритетним завданням органів Національної поліції України є надання поліцейських послуг у сфері забезпечення публічної безпеки й порядку (не будемо дискутувати з приводу понять «публічний та громадський порядок»), а вже потім - охорони прав і свобод людини, а також інтересів суспільства і держави. Не претендуємо на істинну обгрунтованість твердження, однак зі сказаного можна дійти висновку, що забезпечення здійснення того-таки права на свободу мирних зібрань Національною поліцією України можливе виключно внаслідок виконання iï органами завдань із надання поліцейських послуг із забезпечення публічної безпеки й порядку. За таких умов питання охорони права на свободу мирних зібрань витісняється на другий план, що, на наш погляд, суперечить принципові, закладеному в ст. 3 Конституції України, за яким людина, iï життя і здоров'я, честь і гідність, недоторканність і безпека визнаються в Україні найвищою соціальною цінністю. Права і свободи людини та їх гарантії визначають зміст і спрямованість діяльності держави. Безперечно, можна стверджувати, що суспільна стабільність має пріоритет над індивідуальними правами і свободами, оскільки передбачає підтримку стабільності існування суспільного устрою держави в цілому, захищеності державних інтересів, та на фундаменті створеного правопорядку інститути держави охороняють і захищають права і свободи людини. Однак переконані, що саме охорона прав і свобод людини та громадянина, у тому числі й права на свободу мирних зібрань, має бути пріоритетним завданням у наданні поліцейських послуг.

Для системної реалізації вказаних поліцейських послуг (всього 4 їх види), спрямованих на забезпечення здійснення суб'єктивного права на свободу мирних зібрань, поліція повинна володіти певною інформацією про намір суб'єкта здійснити таке право. Цю інформацію органи Національної поліції мають отримувати від органів виконавчої влади та місцевого самоврядування, які є об'єктами сповіщення, єдиного обов'язку суб'єкта здійснення права на свободу мирних зібрань. Водночас наголосимо на тому, що чинні закони України, які регламентують систему та гарантії місцевого самоврядування в Україні, засади організації та діяльності, правового статусу і відповідальності органів та посадових осіб місцевого самоврядування, організацію, повноваження та порядок діяльності місцевих державних адміністрацій та центральних органів виконавчої влади, не визначають обов' язків указаних органів інформувати підрозділи Національної поліції України про надходження сповіщень про намір здійснювати право на свободу мирних зібрань та необхідність надання поліцейських послуг як конкретним особам - суб'єктам здійснення права на свободу мирних зібрань, так і органам публічної адміністрації, суспільству в цілому, спрямованим на забезпечення безперешкодного здійснення права на свободу мирних зібрань та забезпечення публічного порядку й безпеки під час таких мирних зібрань. Зауважимо, що немає нормативно-правового акту Кабінету Міністрів України, який би містив норми, що визначали б порядок взаємодії органів виконавчої влади чи місцевого самоврядування між собою та 3 іншими органами, підприємствами, установами, організаціями, а в окремих випадках і з окремо взятими 
фізичними особами, спрямованими на забезпечення здійснення права на свободу мирних зібрань.

Ось уже 4 роки як існує новий центральний орган виконавчої влади Національна поліція України, однак до цього часу відсутній відомчий нормативноправовий акт, який би детально регламентував повноваження (визначав права та обов'язки посадових осіб органу поліції, у тому числі ї̈ різних структурних підрозділів із урахуванням специфіки їх завдань) поліцейських під час організації та проведення масових заходів, зумовлених здійсненням як окремими громадянами, так i ïx об'єднаннями права на мирні зібрання. Хоча важливість забезпечення законності, прав і свобод громадян диктує необхідність створення правоохоронних органів (або ïx структурних підрозділів - зазначено нами - M. С.), які безпосередньо спеціалізуватимуться на виконанні вказаних завдань [6, с. 81].

Хоча й існують доктринальні погляди на питання організаційного забезпечення здійснення права на свободу мирних зібрань, а точніше, мирних зібрань.

3 огляду на досвід діяльності органів Національної поліції під час проведення масових заходів, О. О. Панова констатує, що процес організації й забезпечення публічної безпеки й порядку поділяється на три етапи: 1) підготовчий, який починається 3 моменту отримання завдання на підтримання публічної безпеки й порядку під час проведення масового заходу; 2) виконавчий, що охоплює дії нарядів і керування ними безпосередньо під час проведення масового заходу; 3) заключний, який здійснюється шляхом згортання сил і засобів, зосередження їх у призначених пунктах та підведення підсумків несення служби [7]. Незважаючи на те, що така структуризація діяльності цілком прийнятна, остання знову ж підтверджує тезу про те, що досліджуються питання саме забезпечення правопорядку під час масових заходів, а не під час здійснення права на свободу мирних зібрань. Перше, що впадає в око, це питання забезпечення публічної безпеки й порядку під час масового заходу, а не під час мирного зібрання, що є різними правовими явищами, хоча, на наш погляд, масовий захід частково охоплює мирне зібрання, оскільки, по-перше, масовий захід може бути й не мирним, а по-друге, мирне зібрання має відбуватися за участі всього лиш однієї особи, що виключає таку ознаку, як масовість учасників у заході. По-третє, така структуризація повноважень Національної поліції притаманна саме забезпеченню правопорядку під час масового заходу, тоді як для забезпечення здійснення права на свободу мирних зібрань остання є дещо скороченою.

Переконані, що ключовим у реалізації повноважень поліції щодо забезпечення здійснення права на свободу мирних зібрань $є$ наявність інформації про намір здійснення даного права, його учасників, місце проведення зібрання тощо. Вочевидь, здобуття такої інформації повинно здійснюватися виключно у відповідності до законодавства України про інформацію та законодавчих актів, що регламентують роботу Національної поліції. Вважаємо, що отримання інформації в межах кримінального процесу та оперативно-розшукової діяльності можливо виключно при надходженні відповідних звернень про вчинення кримінальних правопорушень суб'єктами здійснення права на свободу мирних зібрань або його протиправної мети.

Відтак інформацію про намір здійснювати право на свободу мирних зібрань органи Національної поліції повинні отримувати в порядку, визначеному законом України «Про звернення громадян». Конституція України не встановлює обов' язку суб'єкта здійснення права на мирні зібрання про інформування органів Національної поліції. Водночас органи виконавчої влади або місцевого самоврядування, яким надійшли відповідні сповіщення про проведення мирних 
зібрань, зобов'язані встановити наявність загроз національній безпеці та громадському порядку - 3 метою запобігання заворушенням чи злочинам, для охорони здоров'я населення або захисту прав і свобод інших людей, оскільки виконання вказаних повноважень явно не входить до обов'язків органів виконавчої влади (державних адміністрацій) та місцевого самоврядування - об'єктів сповіщення. Тому органи виконавчої влади та місцевого самоврядування для отримання інформації, що необхідна для виконання ними своїх повноважень, зобов'язані звернутися до уповноважених органів зі зверненнями, у яких мають поінформувати відповідні органи про наявну інформацію про здійснення права на свободу мирних зібрань конкретними суб'єктами та зобов'язані надати висновок про наявність чи відсутність відповідних загроз інтересам національної безпеки та громадського порядку - $з$ метою запобігання заворушенням чи злочинам, для охорони здоров'я населення або захисту прав і свобод інших людей. Така інформація повинна надходити до Служби безпеки України, органів Національної поліції України, Державної служби надзвичайних ситуацій.

Отже, підведемо підсумки: по-перше, органи Національної поліції України мають отримати від об'єкта сповіщення відомості про намір суб'єктом здійснити його право на свободу мирних зібрань; по-друге, органи Національної поліції України зобов'язані надати об'єктові сповіщення відповідний висновок про стан громадському порядку та існування/відсутність потенційних загроз вчинення заворушень чи злочинів, спрямованих на заподіяння шкоди здоров'ю населення або правам і свободам інших людей. Указаний етап можна назвати попереднім, оскільки він не зумовлюється вчиненням будь-яких підготовчих дій, спрямованих на забезпечення здійснення права на свободу мирного зібрання конкретним суб'єктом, а виявляється в наданні аналітичної інформації та прогнозуванні розвитку суспільних явищ (криміногенних факторів), унаслідок здійснення певними суб'єктами їх права на свободу мирних зібрань та наявності в межах установлених законодавством процесуальних дій відомостей про заворушення чи вчинення (готування, замахів) злочинів, а також дій, спрямованих на охорону здоров'я населення або захисту прав і свобод інших людей.

За наявності позитивного висновку щодо відсутності загроз інтересам громадського порядку, Національна поліція має перейти до реалізації підготовчих заходів, спрямованих на забезпечення безперешкодного здійснення права на свободу мирних зібрань, що потребує фактичної інформації ззовні, зокрема й відомостей від самого суб'єкта здійснення права на свободу мирних зібрань.

Відповідно до Закону України «Про інформацію» від 2 жовтня 1992 року, інформація, яка необхідна для поліції, - це соціологічна інформація та інформація про особу. Зазначена інформація, згідно зі ст. ст. 20, 21 Закону України «Про інформацію», належить до інформації відкритої та інформації 3 обмеженим доступом, зокрема тієї, що стосується фізичної особи, а також інформації, доступ до якої обмежено фізичною або юридичною особою. 3 огляду на це, ключовим є зазначення даних про фізичну особу чи юридичну особу - суб'єкта здійснення права на свободу мирних зібрань - такої конфіденційної інформації у сповіщенні про намір здійснення цього права. Однак відсутність законодавчої норми, яка б встановлювала для суб'єкта здійснення права на свободу мирного зібрання відповідного обов' язку унеможливлює законну вимогу до суб' єкта сповіщення, а це є вихідною базовою інформацією для подальших дій поліції із забезпечення публічної безпеки й порядку, охорони прав і свобод людини, інтересів суспільства і держави від 
потенційних загроз та можливих посягань. Зазначену інформацію в межах наявного правого поля повинні подати до органу поліції саме органи виконавчої влади чи місцевого самоврядування, до яких надійшло відповідне сповіщення. Та це далеко не вичерпна інформація, яка потрібна поліцейським для якісного виконання своїх повноважень та забезпечення прав, свобод, інтересів фізичних і юридичних осіб від протиправних посягань, а також забезпечення здійснення права на свободу мирних зібрань.

Під час здійснення суб' єктом його права на свободу мирних зібрань для поліції важливим є уникнення можливих розрізнених (поодиноких) та масових порушень громадського (публічного) порядку, які також можуть призвести до порушення прав, свобод, інтересів фізичних і юридичних осіб, інтересів суспільства та держави. У цьому напрямку важливим є 3'ясування настроїв суб'єктів здійснення права на свободу мирних зібрань, як окремих їх організаторів, так і ініціативних груп [8, с. 153], а також спроможності органів місцевого самоврядування та виконавчої влади забезпечити здійснення права на свободу мирних зібрань шляхом відведення відповідної території чи приміщення, організації роботи відповідних комунальних служб, котрі забезпечують підготовку та прибирання територій, вивезення побутових відходів, які можуть утворитися в результаті проведення мирного зібрання, а також надавання учасникам заходу доступу до електроенергії (за необхідності), залучення суб'єктів господарювання, які надають послуги в цій сфері щодо встановлення сцен, участі в заходах відомих у регіоні, країні політичних, громадських діячів, діячів мистецтва тощо, а також залучення до організації та проведення мирних зібрань інших екстрених служб, зокрема представників підрозділів Державної служби надзвичайних ситуації, служби екстреної медичної допомоги та медицини катастроф, створення майданчиків для розміщення транспорту, підходу та відходу учасників, глядачів, безперешкодного руху перехожих, знаходження відпочиваючих (якщо мирні зібрання проводяться в зонах відпочинку) тощо.

Очевидно, що встановлення порушених питань можливе під час спілкування 3 суб'єктом здійснення права на свободу мирних зібрань, ініціативними групами, посадовими особами органів місцевого самоврядування та виконавчої влади. Відповідно до п. 2 ч. 1 ст. 31 Закону України «Про Національну поліцію», поліція може застосовувати такий превентивний захід як опитування особи. Згідно зі ст. 33 Закону України «Про Національну поліцію», поліцейський може опитати особу, якщо існує достатньо підстав вважати, що вона володіє інформацією, необхідною для виконання поліцейських повноважень. Отже, виходячи із наявних нормативноправових актів, поліція має право опитувати громадян для з'ясування необхідних для виконання поліцією завдань під час підготовки та здійснення суб'єктами їх права на свободу мирних зібрань, у тому числі й з'ясування наявності чи відсутності загроз громадському порядку з метою запобігання заворушенням чи злочинам, для охорони здоров'я населення або захисту прав і свобод інших людей, зумовлених не загальним станом правопорядку та впливу здійснення права на свободу мирних зібрань за певних фактичних обставин, а й створення самим здійсненням права на свободу мирного зібрання своєрідної правової обстановки, приводів та підстав для вчинення протиправних діянь як відносно суб'єктів здійснення права на свободу мирних зібрань, так і стосовно інших людей.

Наступним кроком є встановлення місця здійснення права на свободу мирного зібрання. На цьому етапі поліція повинна встановити, чи буде обмежуватися рух транспорту та чи прийняті відповідні рішення органами місцевого самоврядування 
або виконавчої влади, які повноважені на прийняття таких рішень. Окрім цього, необхідно детально вивчити місце здійснення права на свободу мирного зібрання. Чи відповідає воно безпеці суб'єкта здійснення права на свободу мирного зібрання, учасників, організаторів, випадкових перехожих, мешканщів району тощо, а також уточнення потенційних загроз його проведенню, розпочинаючи від проживання в зоні проведення зібрання осіб, які схильні до протиправної поведінки та можуть дезорганізувати учасників та глядачів такого зібрання, що призведе до порушень законності, закладів торгівлі, де учасники та глядачі мають можливість придбати алкогольні напої, уживання яких потенційно спотворюватиме свідомість учасників, ініціаторів, випадкових спостерігачів, що може призвести до загроз не лише громадському порядку, а й здоров'ю та життю окремих громадян.

Рекогносиирування (розвідка, що провадиться особисто командиром з'єднання, частини або разом $з$ офіцерами штабу перед боєм для виявлення характеру місцевості, розташування сил ворога та одержання інших відомостей, необхідних для організації бойових дій; огляд й обслідування місцевості з метою вибору положень астрономічних і геофізичних опорних пунктів для топографічних зйомок [9]) місцевості на етапі підготовки до забезпечення публічного порядку та безпеки та безпосередньо під час мирного зібрання $є$ вкрай важливим, адже поряд із цим необхідно ретельно вивчити мережу доріг та іншого транспортного сполучення 3 місцем проведення заходу, також можливість визначення альтернативного скерування руху транспорту в разі ускладнення оперативної обстановки, місця стоянки транспорту, вірогідні шляхи підходу (відходу) учасників заходів, їх потенційної евакуації в разі виникнення надзвичайної ситуації або загрози виникнення надзвичайній ситуації. Особлива увага має приділятися технічному стану різноманітних конструкцій, що можуть використовуватися суб'єктом здійснення права на свободу мирного зібрання, організаторами таких мирних зібрань для забезпечення гарантування безпеки його ініціаторів та учасників, випадкових перехожих чи мешканщів прилеглих будинків тощо. На підставі проведених заходів та отриманої інформації прогнозуються потенційні варіанти розвитку ситуацій, що можуть негативно впливати на стан правопорядку, а також дії поліцейських в умовах, що ускладнюють оперативну обстановку. Змушені констатувати, що як для міліції, так і для поліції відсутні відповідні протоколи, нормативно затверджені алгоритми (механізми) дії (заходи, які мають вживатися) в умовах, що ускладнюють оперативну обстановку, а також безпосередньо під час здійснення права на свободу мирних зібрань у різних його формах та спрямуваннях.

Наступне, що слід зробити на підготовчому етапі, - це здійснити загальний розрахунок сил та засобів, що залучатимуться до забезпечення правопорядку під час здійснення права на свободу мирних зібрань. Тут необхідно визначитися із кількістю особового складу поліції, який буде залучатися, а також із притяганням членів громадських формувань з охорони громадського порядку та державного кордону відповідно до Закону України «Про участь громадян в охороні громадського порядку і державного кордону» від 22 червня 2000 року. У подальшому слід визначити підрозділи поліції, з урахуванням завдань, що стоять перед такими підрозділами, поліцейські яких будуть задіяні, - поліцейські секторів превенції, секторів реагування патрульної поліції, поліцейські 3 дорожнього нагляду, ювенальної поліції, дільничних офіцерів поліції, вибухотехнічних та кінологічних служб, задіяння посадовців ізоляторів тимчасового тримання затриманих та взятих під варту осіб, конвоїрів, оперативного складу кримінальної поліції, кадрового забезпечення, 
моніторингу, безпосередньо керівництва відділу (відділення) поліції тощо, а також необхідності створення та розгортання діяльності оперативного штабу (групи оперативного управління) як органу управління нарядами та резервів, а також спеціальних засобів (наприклад, службового автотранспорту). Наступним є визначення чисельності особового складу поліції, який треба залучити до несення служби з охорони публічного порядку та безпеки, аби зазначена кількість була необхідною й достатньою для виконання поставлених завдань та якісного реагування на ускладнення оперативної обстановки.

Визначення із кількістю особового складу та підрозділами, які будуть задіяні до забезпечення публічного (громадського) порядку та безпеки, дозволяє перейти до наступного етапу підготовки до несення служби, а саме визначення місць дислокації нарядів, а також видів нарядів (пости, рухомі наряди, автопатрулі, парні наряди, наряди посилені, резерви тощо), адже одним із ключових питань забезпечення правопорядку є саме вміле розміщення нарядів поліції, аби останні ефективно могли здійснювати нагляд за територією, підозрілими особами для забезпечення безпеки, а також оперативне реагування поліцейськими на будь-які зміни в обстановці та ефективне управління цими нарядами, у тому числі й реагування на факти порушень громадського порядку ${ }^{1}$, будь-які загрози здійсненню права на свободу мирних зібрань. На наш погляд, важливим є створення наряду управління, який безпосередньо на місці здійснюватиме контроль за несенням служби поліцейськими із забезпечення публічної (громадської) безпеки та порядку.

Наступний етап підготовки поліції до несення служби із забезпечення правопорядку із забезпечення здійснення права на свободу мирних зібрань $є$ навчання та підготовка окремих поліцейських та нарядів поліції при виникненні нестандартних ситуацій, визначення конкретних завдань керівникам секторів, нарядів, окремим поліцейським, їх взаємодію. Перш за все є навчання поліцейських законодавчим нормам, що регламентують порядок проведення мирних зібрань та здійснення права на свободу мирних зібрань, права та обов' язки поліцейських під час мирних зібрань та здійснення окремими суб'єктами їх права на свободу мирних зібрань. У контексті сказаного важливим є організація управління силами та засобами, починаючи від забезпечення якісного зв'язку між нарядами поліції та окремими поліцейськими до узгодження прийнятих рішень. Неабияким значущим елементом підготовки поліції до забезпечення публічного порядку та безпеки під час здійснення права на свободу мирних зібрань є визначення засобів, якими будуть екіпіровані поліцейські, котрі будуть використовуватися поліцією під час виконання ними поліцейських послуг. Це і транспорт, який використовуватиметься, і засоби зв' язку, наявність озброєння, вогнепальної зброї та боєприпасів, спеціальних засобів пасивної та активної оборони тощо. Слід приділяти увагу перевірці знань порядку та підстав застосування спеціальних засобів, а також професійного спілкування 3 учасниками мирних зібрань.

Зрештою важливим на етапі підготовки є визначення заходів контролю за підготовкою до несення служби із забезпечення публічного (громадського) порядку та безпеки і безпосереднім несенням служби поліцейськими.

1 Зазначаємо про порушення саме громадського порядку, а не публічного порядку, адже у відповідності до Кримінального кодексу України, Кодексу України про адміністративні правопорушення об'єктом кримінально-правової охорони та охорони 3 боку норм адміністративно-деліктного законодавства є саме громадський порядок та громадська безпека. 
Завершальним етапом $\epsilon$ розроблення письмового плану забезпечення публічного (громадського) порядку та безпеки під час здійснення права на свободу мирних зібрань у конкретній формі, до якого додаткового розроблясться план-схема, у якій відображається характеристика місцевості, маршрути слідування учасників, можливі маршрути відводу учасників заходу, виводу порушників із натовпу, планрозстановка, у якому відображаються місця розташування нарядів поліції, сил та засобів, інших спеціальних та екстрених служб, система їх взаємодії, схеми зв'язку, а також детальні плани-схеми окремих місць чи об'єктів проведення заходів. Зазначена наочна інформація дозволяє доступно роз'яснити поліцейським їхні завдання, сектори впливу (діяльності), маршрути руху тощо. Усе це реалізується на підготовчому етапі до виконання практичних завдань поліцією із забезпечення здійснення права на свободу мирного зібрання та його захисту від будь-яких перешкоджань.

Наступним етапом є безпосереднє забезпечення правопорядку під час мирного зібрання, що стало результатом здійснення права на свободу мирних зібрань. Ключовим на практичному етапі забезпечення публічного (громадського) порядку та безпеки під час здійснення права на свободу мирного зібрання є відповідальне ставлення поліцейськими до виконання своїх повноважень, починаючи від чіткого усвідомлення завдань, які ставляться перед кожним поліцейським, закінчуючи готовністю поліцейських до дій в екстремальних ситуаціях, таких як: вчинення адміністративного чи кримінального правопорушення, звернення за допомогою окремих осіб, звернення представників засобів масової інформації з будь-яких питань ïx професійної діяльності, у тому числі й перешкоджання діяльності журналіста тощо. Ураховуючи всі вжиті заходи на підготовчому етапі, на практичному етапі реалізації заходів першорядним є ефективне, оперативне управління нарядами, уміле маневрування ними, забезпечуючи тим самим припинення будь-яких замахів на громадський порядок, життя, здоров'я, права, свободи та інтереси людини і громадянина. У контексті сказаного важливим $є$ ведення відеофіксації мирного зібрання.

Окрім цього, встановлення відеокамер повинно бути стаціонарним або ж слугувати елементом однострою поліцейських. Лише за таких умов здійснення відеозапису буде законним та не порушуватиме права людини.

Поліцейські під час підготовки та забезпечення правопорядку під час мирного зібрання можуть використовувати такий превентивний поліцейський захід, як вимогу залишити місце чи обмежити доступ на визначену територію, оскільки даний превентивний поліцейських захід може бути застосований для забезпечення публічної безпеки й порядку, охорони життя і здоров'я людей, для збереження та фіксації слідів правопорушення (ст. 36 Закону України «Про Національну поліцію»).

Не слід забувати і про повноваження поліції після завершення мирного зібрання. Звісно, воно пройшло без порушень норм чинного законодавства, у поліцейських виникає єдине завдання - проаналізувати дії поліцейських, їх ефективність щодо забезпечення публічного порядку та безпеки під час мирного зібрання, надання поліцейських послуг суб'єктові здійснення права на мирні зібрання, іншим учасникам мирного зібрання, пересічним громадянам. Зазначені дії $\epsilon$ важливими для відпрацювання тактики дій поліцейських із забезпечення публічного порядку та безпеки під час мирних зібрань, обставин, що ускладнюють оперативну обстановку, урахування позитивного досвіду та недопущення помилок у службовій діяльності під час проведення мирних зібрань у аналогічній та інших 
формах, а також на вказаній місцевості (у приміщенні) чи на іншій території, забезпечення прав, свобод та інтересів людини і громадянина.

У разі ж вчинення адміністративних чи кримінальних правопорушень під час здійснення права на свободу мирного зібрання, після завершення зібрання здійснюються відповідні слідчі (розшукові) дії, у тому числі негласні слідчі (розшукові) дії в межах досудового розслідування кримінального провадження або ж процесуальні дії, передбачені законодавством про адміністративні правопорушення.

Після здійснення права на свободу мирного зібрання важливим є аналіз поліцейськими причин та умов вчинення адміністративних та кримінальних правопорушень 3 метою усунення вказаних негативних факторів під час забезпечення публічного порядку та безпеки під час здійснення права на свободу мирних зібрань вказаними чи іншими суб' єктами.

Висновки. Підводячи підсумок дослідженню питання повноважень органів Національної поліції під час забезпечення здійснення права на мирні зібрання, слід чітко розмежувати повноваження органів Національної поліції на трьох основних етапах щодо забезпечення правопорядку під час мирних заходів: 1) під час підготовки до проведення мирного зібрання; 2) під час мирного зібрання. 3) після завершення мирного зібрання та чотирьох під час здійснення права на свободу мирних зібрань: 1) попередній; 2) підготовчий; 3) практичний; 4) завершальний (підсумковий). Безперечно, найважливішим є діяльність із забезпечення здійснення права на мирні зібрання саме під час проведення самого зібрання, однак якісна підготовка, знання інформації про можливі ускладнення оперативної обстановки, наявність достатніх умінь та навичок із виконання завдань $є$ гарантом якісного виконання посадових обов'язків поліцейськими із забезпечення здійснення права на мирні зібрання.

Таким чином, доходимо висновку про те, що повноваження органів Національної поліції України під час здійснення права на свободу мирних зібрань надто розмиті, а подекуди - взагалі не визначені. Такий стан справ не сприяє утвердженню законності в діяльності органів виконавчої влади, сприяючи необгрунтованому або свавільному ставленню до організаторів, суб'єктів здійснення права на свободу мирних зібрань, тим самим ставлячи під загрозу права, свободи та інтереси людини і громадянина, а також формулює поведінку представників органів Національної поліції України, яка подекуди викликає супротив в учасників зібрань, випадкових перехожих, мешканців прилеглих до зібрання будинків, оскільки поліцейські не в змозі прореагувати на поведінку окремих учасників зібрань, котра, 3 огляду на все, є антисуспільною, однак не містить ознак адміністративних чи кримінальних правопорушень [6, с. 152-157].

Переконані, що суб'єкти правотворення та законотворення, суб'єкти законотворчої та правотворчої ініціативи мають найближчим часом розробити нормативні правила, що визначатимуть повноваження органів Національної поліції України, спрямовані на забезпечення здійснення права на свободу мирних зібрань, недопущення безпідставного та протиправного обмеження здійснення даного права, а також гарантування охорони індивідуальних та суспільних інтересів під час здійснення окремими суб'єктами їх права на свободу мирних зібрань.

\section{Використані джерела:}

1. Долинний А. В. Адміністративно-правове забезпечення Національною поліцією України публічної безпеки і порядку під час проведення масових заходів: дис... канд. юрид. наук. по спец.: 12.00.07 - адміністративне право і процес; інформаційне право. К., 2017. 198 с. 
2. Поліщук $\quad$ B. Г. Адміністративно-правове регулювання та практика проведення масових заходів : автореф. дис... канд. юрид. наук. по спец.: 12.00 .07 адміністративне право і процес; інформаційне прав. Х., 1999. 17 с.

3. Возник М. В. Організаційно-правові засади управління органами внутрішніх справ при забезпеченні масових заходів : автореф. дис. ... канд. юрид. наук по спец.: 12.00.07 - адміністративне право і процес; інформаційне право. К., 2010. 20 с.

4. Нестерович В. Ф. Зарубіжний досвід конституційно-правового регулювання проведення мирних зібрань громадян. Науковий вісник Дніпропетровського державного університету внутрішніх справ. 2015. № 3. С. 55-63.

5. Нестерович $\quad$ В. Ф. Проблеми конституційно-правового регулювання проведення мирних зібрань громадян в Україні. Вісник Луганського державно-го університету внутрішніх справ імені Е. О. Дідоренка. 2018. № 2. С. 47-59.

6. Толкачев К. Б. Органы внутренних дел в механизме обеспечения личных конституционных прав и свобод граждан: монография/ К.Б. Толкачев, А.Г. Хабибулин. Уфа, Уфимская высш. школа, 1991. 168 с.

7. Панова О. О. Організація діяльності органів поліції щодо підтримання публічної безпеки та порядку під час проведення масових заходів / / S.P.A.C.E. Society, Politics, Administration in Central Europe : електронний науково-практичний журнал / редкол.: Д. В. Яковлев, К. М. Вітман, Д. Ю. Дворніченко; НУ «ОЮА». Одеса, 2017. Вип. 2. C. 42-46. URL: http:/ / dspace.onua.edu.ua/handle/11300/7332. (дата звернення 12.07.2019)

8. Самбор М. А. Повноваження поліції щодо забезпечення права на мирні зібрання // Актуальні питання забезпечення публічного порядку та безпеки в сучасних умовах: вітчизняний та міжнародний досвід: матеріали Міжнар. наук.практ. конф. (Дніпро, 17 листоп. 2017 р.). Дніпро: Дніпроп. держ. ун-т внутр. справ; Ліра ЛТД, 2017. с. 152-157.

9. Рекогносцирування. Словник іншомовних слів Мельничука. URL: http:/ / slovopedia.org.ua/42/53408/289202.html. (дата звернення 24.04.2017).

10. Правокультурные основы исследования государственной власти: теоретико-методологические, историко-правовые и ценностно-нормативные аспекты: монография / Г. И. Авцинова, В. Я. Любашищ, А. Ю. Мамычев, А. Ю. Мордовцев, А. И. Овчинников и др. М.: Юрлитинформ, 2014. 480 с.

11. Конституція України: прийнята на п'ятій сесії Верховної Ради України 28 червня 1996 року. Відомості Верховної Ради Украӥни. 1996. № 30. Ст. 141.

12. Про Національну поліцію: Закон України від 2 липня 2015 року № 580-VIII. Відомості Верховної Ради України. 2015. № 40-41. Ст. 379.

\section{References:}

1. Dolynnyi, A. V. (2017) Administratyvno-pravove zabezpechennia Natsionalnoiu politsieiu Ukrainy publichnoi bezpeky i poriadku pid chas provedennya masovykh zakhodiv. Candidate's thesis. Kyiv. [in Ukrainian].

2. Polishchuk, V. H. (1999) Administratyvno-pravove rehulyuvannya ta praktyka provedennya masovykh zakhodiv. Extended abstract of candidate's thesis. Kharkiv. [in Ukrainian].

3. Voznyk, M. V. (2010) Orhanizatsiyno-pravovi zasady upravlinnya orhanamy vnutrishnikh sprav pry zabezpechenni masovykh zakhodiv. Extended abstract of candidate's thesis. Kyiv. [in Ukrainian].

4. Nesterovych, V.F. (2015) Zarubizhnyy dosvid konstytutsiyno-pravovoho rehulyuvannya provedennya myrnykh zibran' hromadyan. Naukovyy visnyk 
Dnipropetrovs'koho derzhavnoho universytetu vnutrishnikh sprav - Scientific Bulletin of Dnipropetrovsk State University of Internal Affairs, 3, 55-63. [in Ukrainian].

5. Nesterovych, V. F. (2018) Problemy konstytutsiyno-pravovoho rehulyuvannya provedennya myrnykh zibran' hromadyan v Ukrayini. Visnyk Luhans'koho derzhavno-ho universytetu vnutrishnikh sprav imeni E. O. Didorenka - Bulletin of the Luhansk State University of Internal Affairs named after E. O. Didorenko, 2, 47-59. [in Ukrainian].

6. Tolkachev, K. B., Khabibulin, A. G. (1991) Organy vnutrennikh del v mekhanizme obespecheniya lichnykh konstitutsionnykh prav i svobod grazhdan. Ufa: Ufa higher. Damage. [in Russian].

7. Panova, O. O. (2017) Orhanizatsiya diyal'nosti orhaniv politsiyi shchodo pidtrymannya publichnoyi bezpeky ta poryadku pid chas provedennya masovykh zakhodiv. S.P.A.C.E. Society, Politics, Administration in Central Europe: elektronnyi naukovopraktychnyi zhurnal - S.P.A.C.E. Society, Politics, Administration in Central Europe: Electronic Journal of Science. Odesa, Vip. 2, 42-46. URL: http://dspace.onua.edu.ua/handle/11300/7332. [in Ukrainian]

8. Sambor, M. A. (2017) Povnovazhennya politsiyi shchodo zabezpechennya prava na myrni zibrannya. Aktualni pytannia zabezpechennia publichnoho poryadku ta bezpeky v suchasnykh umovakh: vitchyznianyi ta mizhnarodnyi dosvid. Materialy Mizhnar. nauk. prakt. konf. (Dnipro, 17 lystop. 2017 r.)-Current issues of ensuring public order and safety in modern conditions: domestic and international experience (Dnipro, November 17. 2017). Dnipro: Dniprop. derzh. un-t vnutr. sprav; Lira LTD, 152-157. [in Ukrainian].

9. Rekohnostsyruvannia [Reconnaissance] Slovnyk inshomovnykh sliv Melnychuka. N. d. N. p. URL: http:// slovopedia.org.ua/42/53408/289202.html. [in Ukrainian].

10. Pravokul'turnyye osnovy issledovaniya gosudarstvennoy vlasti: teoretikometodologicheskiye, istoriko-pravovyye i tsennostno-normativnyye aspekty: monografiya (2014). G. I. Avtsinova, V. YA. Lyubashits, A. YU. Mamychev, A. YU. Mordovtsev, A. I. Ovchinnikov (Eds.) et al. Moskva: Yurlitinform. [in Russian].

11. Konstytutsiya Ukrayiny: pryynyata na p"yatiy sesiyi Verkhovnoyi Rady Ukrayiny 28 chervnya 1996 roku. Vidomosti Verkhovnoyi Rady Ukrayiny - Information of the Verkhovna Rada of Ukraine, 30, art. 141. [in Ukrainian].

12. Pro Natsional'nu politsiyu: Zakon Ukrayiny vid 2 lypnya 2015 roku № 580-VIII. Vidomosti Verkhounoyi Rady Ukrayiny - Information of the Verkhovna Rada of Ukraine, 40-41, art. 379.

Стаття надіӥшла до редколегї 03.11.2019

Самбор Н. А., кандидат юридических наук, начальник сектора мониторинга

Прилуцкого отдела полиции

Главного управления Национальной полиции в Черниговской области (г. Чернигов - г. Прилуки, Украина)

\section{ПОЛНОМОЧИЯ ОРГАНОВ НАЦИОНАЛЬНОЙ ПОЛИЦИИ УКРАИНЫ ПРИ ОБЕСПЕЧЕНИИ ОСУЩЕСТВЛЕНИЯ ПРАВА НА СВОБОДУ МИРНЫХ СОБРАНИЙ}

В праве в постоянной взаимосвязи находятся такие парные категории, как права и обязанности. Право на свободу мирных собраний не является исключением, а 
потому корреспондируется с обязанностями субъектов публичной администрации, задачей которых является обеспечение беспрепятственного осуществления права на свободу мирных собраний. В статье детально рассмотрены полномочия органов Национальной полиции Украины, направленные на обеспечение осуществления права на свободу мирных собраний. Обоснована необходимость разграничения полномочий органов Национальной полиции на трех основных этапах по обеспечению правопорядка во время мирных мероприятий: 1) при подготовке к проведению мирного собрания; 2) во время мирного собрания. 3) после завершения мирного собрания; а также на четырех этапах обеспечения беспрепятственного осуществления права на свободу мирных собраний органами Национальной полищии Украины: 1) предварительный; 2) подготовительный; 3) практический; 4) заключительный (итоговый).

Ключевые слова: право на свободу мирных собраний, полномочия, Национальная полиция Украина.

Sambor M.

Candidate of Law, Head of the monitoring Department of the Pryluky

Police Department the Main Directorate of the National Police in Chernihiv Oblast (Chernihiv - Pryluky, Ukraine)

\section{POWERS OF THE BODIES OF THE NATIONAL POLICE OF UKRAINE IN ENSURING OF THE RIGHT TO FREEDOM OF PEACEFUL ASSEMBLY}

In the right in the constant relationship there are such pairs categories as rights and responsibilities. The right to freedom of peaceful assembly is not an exception, and therefore corresponds to the duties of the subjects of public administration whose task is to ensure the unimpeded exercise of the right to freedom of peaceful assembly. The powers of the National Police of Ukraine in the field of ensuring the exercise of the right to freedom of peaceful assembly are researched. The powers of the bodies of the National Police of Ukraine, aimed at ensuring the exercise of the right to freedom of peaceful assembly, are considered in detail.

The necessity of differentiating the powers of the National Police in three main stages in ensuring law and order during peaceful measures is substantiated: 1) during the preparation for the peaceful assembly; 2) during the peaceful assembly. 3) upon the completion of the peaceful assembly; as well as at the four stages of ensuring the unimpeded exercise of the right to freedom of peaceful assembly by the bodies of the National Police of Ukraine: 1) preliminary; 2) preparatory; 3) practical; 4) final (final).

The powers of the bodies of the National Police of Ukraine in the exercise of the right to freedom of peaceful assembly are too vague and, in some cases, not defined at all. Such a state of affairs does not contribute to the assertion of legitimacy in the activities of executive authorities, promoting unreasonable or arbitrary treatment of the organizers, subjects of the exercise of the right to freedom of peaceful assembly, thereby endangering the rights, freedoms and interests of the individual and citizen, as well as formulating the behavior of representatives of the bodies of the National Police of Ukraine, which sometimes provokes opposition among the participants of the meetings, accidental passers-by, residents of the adjacent houses, since the police are not able to react behavior of individual members of 
assembly, which is given is antisocial, but contains no signs of administrative or criminal offenses.

It is argued that the subjects of the lawmaking and law-making initiative should in the near future develop normative acts that will determine the powers of the bodies of the National Police of Ukraine aimed at ensuring the exercise of the right to freedom of peaceful assembly, preventing unjustified and unlawful restrictions on the exercise of this right, and guaranteeing the protection of individual and social interests in the exercise by individual subjects of their right to freedom of peaceful assembly.

Key words: the right to freedom of peaceful assembly, powers of the National Police of Ukraine.

DOI: $10.33766 / 2524-0323.88 .147-157$

УДК 343.98

О. С. Соколов,

завідувач відділу досліджень зброї лабораторії досліджень, сертифікації зброї та обліку

Державного науково-дослідного експертно-криміналістичного центру МВС України

(м. Київ, Україна)

e-mail: ballistekc@gmail.com

iD https://orcid.org/0000-0001-7613-1590

\section{ПЕРСПЕКТИВИ РЕФОРМУВАННЯ УКРАЇНСЬКОГО ЗАКОНОДАВСТВА У СФЕРІ ОБІГУ ЗБРОЇ З УРАХУВАННЯМ ПОЛОЖЕНЬ СВРОПЕЙСЬКИХ ПРАВОВИХ АКТІВ}

Ураховуючи положення Конституції України щодо стратегічного курсу держави на набуття повноправного членства в Свропейському Союзі, у статті розглянуто основні положення директив, регламентів та інших правових актів Свропейського Союзу, які стосуються сфери контролю над легким озброєнням і стрілецькою зброєю, а також проведено їх порівняльний аналіз з положеннями існуючих національних нормативноправових актів, що регулюють сферу обігу цивільної зброї в Україні. Розглянуто основні вимоги європейського законодавства щодо контролю за обігом зброї, які $є$ обов'язковими для імплементації в національне законодавство країн-членів та країнкандидатів на вступ до Європейського Союзу. Проведено порівняльний аналіз положень українського та європейського законодавств, які стосуються категорій забороненої зброї та зброї, цивільний обіг якої $є$ обмеженим. Розглянуто основні положення законодавчих ініціатив Верховної Ради України, направлених на правове врегулювання обігу зброї в Україні та проведено порівняння їх основних положень із положеннями правових актів Свропейського Союзу. Запропоновано найкращі рішення щодо гармонізації українського національного законодавства у сфері контролю над стрілецькою зброєю та легким озброєнням відповідно до права Європейського Союзу.

Ключові слова: Директива ЄС, Регламент СС, імплементація, категорії зброї, гармонізація законодавства.

Постановка проблеми. Конституцією України закріплений стратегічний курс держави на набуття повноправного членства в Свропейському Союзі (далі - СС). 3 метою реалізації зазначеного курсу, Верховною Радою України

(С) Соколов О. С., 2019 